\title{
Genç Sürücü Davranışlarının Trafik Güvenliği Konseptinde Analizi
}

\author{
Hakan Aslan \\ Mühendislik Fakültesi, İnşaat Mühendisliği Bölümü, Sakarya Üniversitesi, Türkiye
}

\section{$\ddot{O} \mathbf{z}$}

Sadece ülkemizin değil tüm dünyanın başa çıkmaya çalıştığı önemli bir sorun olan trafik kazaları, dünyada milyonlarca can almakta ve çok büyük ekonomik kayıplara neden olmaktadır. Genç yaşta ölümlerin başlıca sebepleri arasında olan trafik kazaları, üzerinde önemle durulması gereken bir problem olarak ulaşım mühendislerinin gündeminde yerini almıştır. Sürücülerin tamamına göre büyük bir oranı temsil etmemekle beraber, genç sürücülerin (18-25 yaş) diğer sürücülere göre ölümcül ve yaralanmalı kazalara karışma oranları daha yüksektir. Bu çalışmanın ana hedefi; genç sürücülerin trafik kurallarına uyum karakterlerini belirlemek ve genç sürücülerin ölümlü ve yaralanmalı kazalara karışma düzeylerini ve ortaya çıkan matematiksel tabloyu ülkemiz açısından ortaya koymaktır

Anahtar Kelimeler: Yol güvenliği, genç sürücüler, trafik kazaları

\begin{abstract}
Traffic accidents, which are an important problem not only for our country but also for the whole world, take millions of lives and cause enormous economic losses. Among the major causes of death at a young age, traffic accidents have been placed on the agenda of the transportation engineers as a crucial problem. The majority of young drivers (18-25 years) are more likely to be involved in fatal and injury related accidents compare to other drivers. The main objective of this study is to determine the adaptation characteristics of young drivers to traffic rules and to reveal the level of involvement of young drivers in fatal and injury accidents and the resulting mathematical table for our country.
\end{abstract}

Key words: Road safety, young drivers, traffic accidents

*Corresponding author: Address: Faculty of Engineering, Department of Civil Engineering Sakarya University, 54187, Sakarya TURKEY. E-mail address: haslan@sakarya.edu.tr, Phone: +902642955752 


\section{Giriş}

Gündelik insan yaşamının en temel ihtiyaçlarından biri olan hareketlilik olgusuna cevap vermek üzere ortaya çıkan trafik konsepti, sağladığı imkanların yanında bir çok olumsuzluğu da bünyesinde barındırmaktadır. Bunların başında trafik kazaları ve bunlara bağlı olarak kendisini gösteren ölümler ve yaralanmalar gelmektedir. Ülkemiz için de oldukça önemli bir sorun olan trafik kazalarındaki can ve mal kayıpları, üzerinde dikkatle durulması gereken bir alandır. Emniyet Genel Müdürlüğü Trafik İstatistik Bülteni verilerine göre 2017 yılında Türkiye de 410.612 kaza gerçekleşmiş olup, bu kazaların 6.400 ü ölümle, 176.269`u yaralanma ile sonuçlanmıştır. Bu kazalarda hayatını kaybeden kişi sayısı 7427 (günde 20 kişi), yaralanan sayısı ise 300.383 ( günde 823 kişi ) olarak açıklanmıştır. 2018 yılı verilerine bakıldığında ise, OcakAğustos döneminde gerçekleşen toplam 289.167 kazanın 1.905 i ölümlü kaza statüsünde olup, bu kazalarda olay yerinde 2.383 ( bir aylık hastane sürecinde ölenlerde dikkate alındığında 4800 civarında ) kişi hayatını kaybederken, 218.004 kişi de yaralanmıştır. İnsan hayatının değerinin rakamsal ifadesi mümkün olmamakla beraber, ürkütücü ve müdahale edilmesi gereken bir problemle karşı karşıya olunduğu açıktır.

Birleşmiş Milletler Genel Kurulunun 2 Mart 2010 tarihli toplantısında küresel ölçekli trafik güvenliği sorunu ele alınmış ve 2011-2020 yılları arasında karayolları trafik güvenliğinin sağlanması ve trafik kazalarından kaynaklı ölüm hadiselerinin \%50 oranında azaltılması amacıyla "Küresel Yol Güvenliğinin Iyileştirilmesi" hakkında 64/255 sayılı karar alınmıştır. Alınan bu karar çerçevesinde, ülkemiz karayollarında meydana gelen trafik kazalarının önlenmesi, trafik kazalarından kaynaklanan ölüm ve yaralanmaların önemli ölçüde azaltılarak sonuçlarının hafifletilmesi amaciyla Emniyet Genel Müdürlüğünün koordinatörlüğünde, ilgili kurum ve kuruluşlarla işbirliği yapılarak "Trafik Güvenliği Starejik Eylem Planı" hazırlanması planlanmıştır. Emniyet Genel Müdürlügü ve YÖK arasında bu plan içeriğinde bir protokol hazırlanarak hayata geçirilmiştir.

Karayolları Genel Müdürlüğünün açıkladığı verilere gore, 2010-2017 yılları arasında ölenlerin sayıları aşağıdaki tablo da ifade edilmiştir.

Tablo 1. Türkiye'de her 1 milyon kișide trafik kazalarında ölen kiși sayıları/oranları, KGM

\begin{tabular}{ccccccccc}
\hline & $\mathbf{2 0 1 0}$ & $\mathbf{2 0 1 1}$ & $\mathbf{2 0 1 2}$ & $\mathbf{2 0 1 3}$ & $\mathbf{2 0 1 4}$ & $\mathbf{2 0 1 5}^{*}$ & $\mathbf{2 0 1 6}^{*}$ & $\mathbf{2 0 1 7}^{*}$ \\
\hline $\begin{array}{c}\text { Ölen Kişi } \\
\text { Sayısı }\end{array}$ & 4045 & 3835 & 3750 & 3685 & 3524 & 7530 & 7300 & 7427 \\
Nüfus & 73.722 .988 & 74.724 .269 & 75.627 .384 & 76.667 .864 & 77.695 .904 & 78.741 .053 & 79.814 .871 & 80.810 .525 \\
$\begin{array}{c}\text { Ölüm } \\
\text { Oranları }\end{array}$ & 54,868 & 51,322 & 49,58 & 48,06 & 45,36 & 95,63 & 91,461 & 91,92 \\
\hline
\end{tabular}

* $\mathrm{Bu}$ yıllarda hastahanede 30 gün içinde vefat edenler de verilere dahil edilmiştir.

Trafik kazaları; insan faktörü ile ortamsal özelliklerin (özellikle yol, hava ve araç özellikleri) etkileşimi sonucunda oluşur. İnsan faktörü bu etkileşimde bazen aktif (örneğin hatalı sollama gibi bir kural ihlali yaparak) bazen de pasif bir etmen (yorgun ve dikkatsiz araç kullanma, yol ve trafik koşuıllarına dikkate etmeme vb.) olarak çoğu zaman baş rolü oynamaktadır. İnsan faktörü; 
araç kullanma sıklığından, sürücülerin demografik özelliklerine, psikomotor becerilerden kişilik özelliklerine kadar geniş bir yelpazede değerlendirilebilir.

Sürücülerin yaşı dikkate alındığında ise 18-25 yaşları arsındaki genç sürücülerin en riskli grubu oluşturdukları görünmektedir [1]. Yapılan bir araştırmada [2], genç sürücülerin, özellikle erkek sürüclerin, yüksek oranda trafik kazalarına karışmalarına neden olarak aşağıdaki temel unsurlar ortaya konulmuştur.

- $\quad$ Risk almaya olan göreceli yüksek eğilim

- Güvenlik ve koruma özellikleri daha düşük olan yaşlı araç kullanımı

- Yol ve trafik koşullarının gerektirdiği araç kullanma hızından daha yüksek hızda araç kullanma

- Takip mesafesine uygun şekilde araç kullanmama

- Kırmızı ışık ihlalleri

Yeni Zelanda da yapılan bir araştırmaya gore [3], 20-24 yaş grubundaki gençler tüm ehliyet sahipleri içinde \%9 luk orana sahip iken, maddi hasarlı kazalarda \% 15, ciddi yaralanmalı ve ölümlü kazalarda ise \% 14 oranında bir paya sahiptirler. Aynı araştırma sonuçlarına gore 15-24 yaş aralığında 2010-2012 yılları arasında ölümcül, ciddi yaralanmalı ve maddi hasarlı kazalara karışanların sırası ile \% 78, \% 69 ve \% 61 `inin erkek olduğu görülmektedir.

Bu çalışmanın genel konsepti ve inceleme alanı itibari ile Emniyet Genel Müdürlüğü’nden elde edilen veriler analiz edilerek, ülkemizde trafik kazalarına bağlı olarak 18-25 yaş aralığındaki gençlerin genel problem içerisindeki rolü ve etkisi incelenmiştir. Aşağıdaki bölümde bu analiz sonuçları sunulmuştur.

\section{18-25 yaş Aralığı için Trafik Kazaları Veri Analizleri}

Bu makaledeki çalışma alanına uygun veriler, Emniyet Genel Müdürlügü Veri Bankası genel verilerinden filtrelenerek tedarik edilmiş ve belli parametrelere göre analizler yapılmıştır. Yaş grubu olarak 18-25 yaş aralığı seçildiği için, analizler bu grup için yoğunlaştırılmış olup, genel karşılaştırma ve değerlendirme amaçlı olarak, diğer yaş gruplarına ait veriler de incelemeye alınmıştır.

2000-2017 yılları arasında ülkemizde meydana gelen kazalara bağlı olarak 18-25 aralığında sürücü olarak hayatını kaybedenlerle ilgili veriler aşağıdaki şekillerde sunulmuştur. 

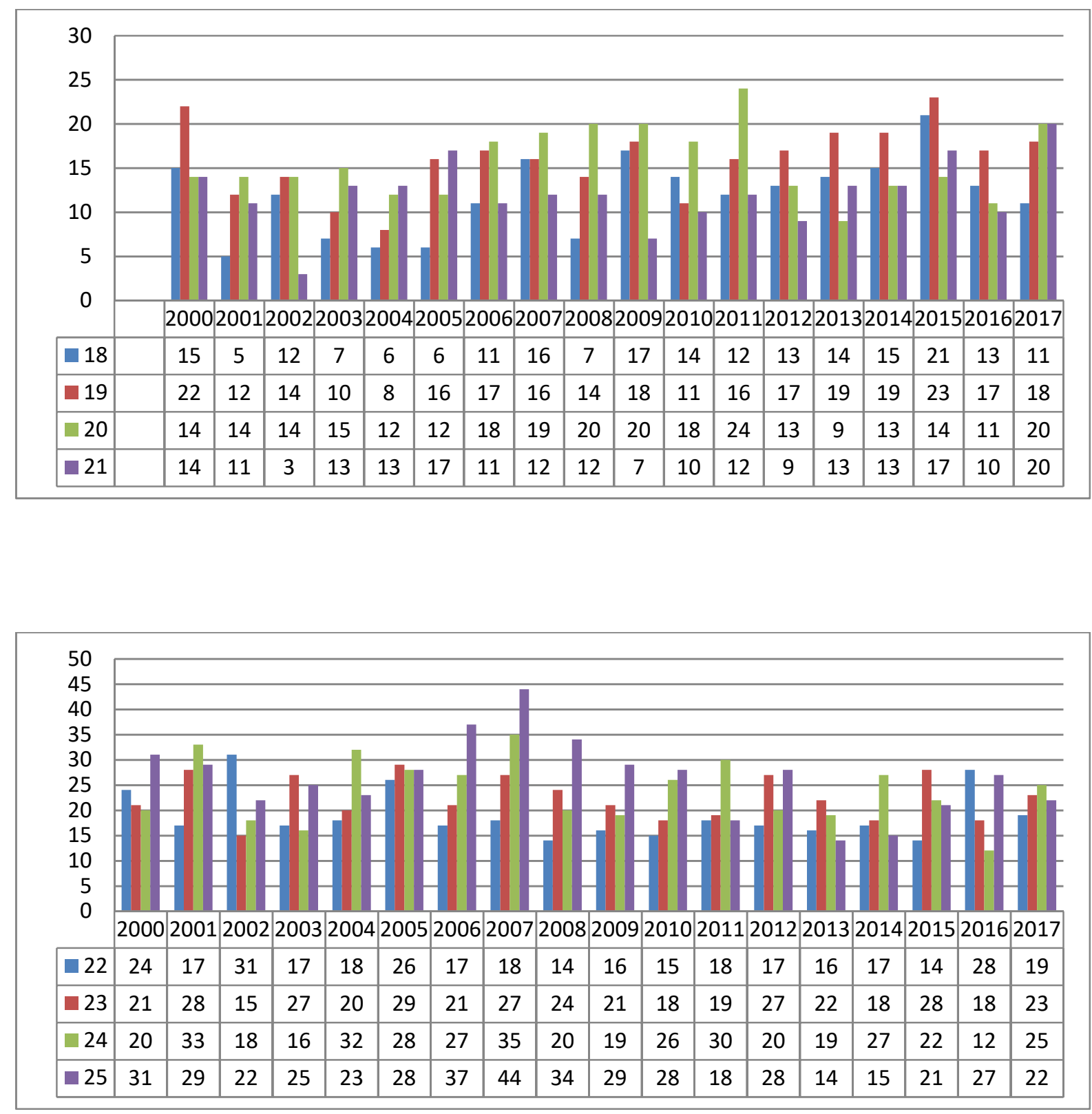

Şekil 1.a-b. 2000-2017 yılları arasında trafik kazalarında ölen 18-25 yaş aralığındaki erkeklerin sayıları

Yaş grupları verilerine bağlı olarak yapılan lineer regresyon analizleri sonuçları aşağıdaki tabloda özetlenmiştir. 
Tablo 2. 2000-2017 yılları arası 18-25 yaş aralığı erkek ölümleri Lineer Regresyon Analizleri

\begin{tabular}{cccccc}
\hline Yaş Grubu & $\begin{array}{c}\text { Regresyon } \\
\text { Denklemi }\end{array}$ & $\begin{array}{c}\text { Örneklem } \\
\text { Sayısı }\end{array}$ & $\mathbf{R}^{\mathbf{2}}$ Değeri & $\begin{array}{c}\text { Standart } \\
\text { Hata }\end{array}$ & $\begin{array}{c}\text { Standart } \\
\text { Sapma }\end{array}$ \\
\hline $\mathbf{1 8}$ & $0.4 \mathrm{x}+8.15$ & 18 & 0.24 & 3.92 & 4.36 \\
$\mathbf{1 9}$ & $0.1476 \mathrm{x}+13.986$ & 18 & 0.03 & 4.3712 & 4.313 \\
$\mathbf{2 0}$ & $0.0433+15.143$ & 18 & 0.003 & 4.0738 & 3.958 \\
$\mathbf{2 1}$ & $0.2136 \mathrm{x}+10.026$ & 18 & 0.09 & 3.7486 & 3.811 \\
$\mathbf{2 2}$ & $-0.231 \mathrm{x}+21.196$ & 18 & 0.06 & 4.874 & 4.887 \\
$\mathbf{2 3}$ & $-0.085 \mathrm{x}+23.359$ & 18 & 0.011 & 4.365 & 4.259 \\
$\mathbf{2 4}$ & $-0.251 \mathrm{x}+26.216$ & 18 & 0.044 & 6.403 & 6.354 \\
$\mathbf{2 5}$ & $-0.552 \mathrm{x}+31.633$ & 18 & 0.154 & 7.117 & 7.508 \\
\hline
\end{tabular}

18-25 yaş erkek grubu için gerçekleşen ölüm ve yaralanmalar ile ilgili irdeleme ve değerlendirmeler aşağıdaki şekillerde sunulmuş ve analiz edilmiştir.

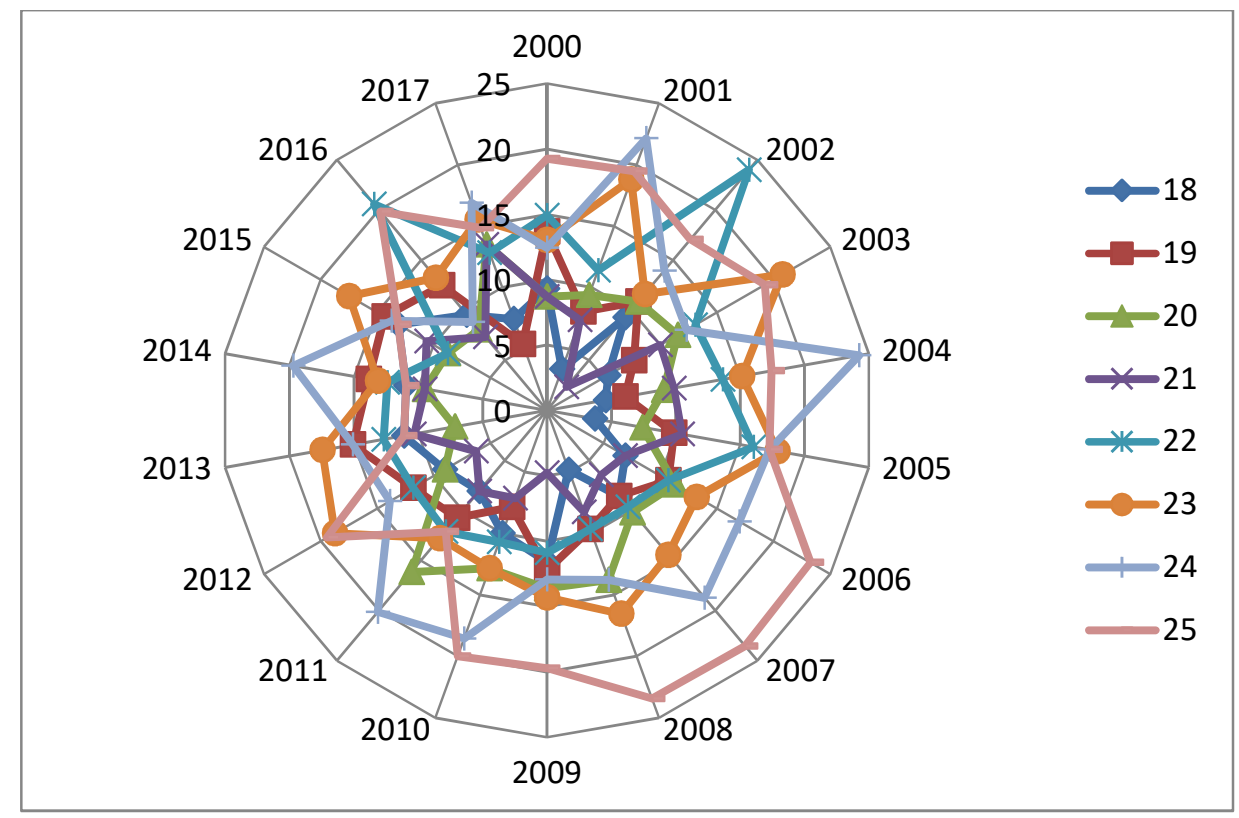

Şekil 2. 2000-2017 yılları arası yaş gruplarının kendi içlerindeki erkek ölüm yüzdeleri

Ölüm oranları açısından yukarıdaki şekil incelendiğinde 22-25 yaş aralığındaki grupların daha yüksek ölüm yüzdelerine sahip oldukları görülmektedir. 2002 ve 2016 yıllarında \%24.03 ve 20.59 oranlarıyla 22 yaş grubu, 2003, 2005 ve 2013 yıllarında \% 20.77, \%17.90 ve \%17.46 oranlarıyla 23 yaş grubu, 2001,2004, 2011, 2014 ve 2017 yıllarında \%22.15, \%24.24, \%20.13, $\% 19.71$ ve $\% 16.89$ oranları ile 24 yaş grubu, 2000,2006,2007,2008,2009, 2010 ve 2012 yıllarında ise $\% 19.25, \% 23.27, \% 23.53, \% 23.44, \% 19.73, \% 19.44$ ve $\% 24.0$ oranları ile 25 yaş grubunun en yüksek ölüm yüzdelerine sahip oldukları görülmektedir. 18 yıllık periyodda 12 yıllık dönem için 24 ve 25 yaş grubunun öne çıktığı sonucu ifade edilebilir. Dolayısı ile bu yaş gruplarının kaza 
eğilimleri, risk alma davranışları ve araç kullanım tarzları daha detaylı incelenerek, problemin temel yapısına dönük anlamlandırma çalışmaları yapılmalıdır.

En düşük ölüm oranlarının olduğu gruplara bakıldığında 2001, 2003, 2004, 2005, 2006 ve 2011 yılları arasında 18 yaş grubunun $\% 3.55, \% 5.38, \% 4.54, \% 3.7, \% .91, \% 4.83$ ve $\% 8.05$ ölüm oranlarına; 19 yaş grubunun 2017 yılında \%5.41 oranına; 20 yaş grubunun 2000, 2013 ve 2015 y1llarında \%8.69, \%7.14 ve \%8.75 oranlarına; 21 yaş grubunun da 2002, 2007, 2009, 2010, 2012, 2014 ve 2016 yıllarında $\% 2.32, \% 6.42, \% 4.76, \% 7.14, \% 6.25, \% 9.49$ ve $\% 7.35$ oranlarına sahip olduğu görülmektedir. 22 yaş grubunun en düşük ve en yükek ölüm oranlarına sahip olma anlamında kritik bir eşik olduğu söylenebilir. 22 yaş ve üstünün incelemeye konu olan yıllar açısından en düşük ölüm oranlarına sahip yaşlar olmada $\% 0$, en yüksek oranlara sahip olmada ise \% 94.44 lük bir orana sahip oldukları görülmektedir. Bu durumun ortaya çıkma sebebi olarak, belli bir düzeyde mekanik olarak araç kullanma becerilerini geliştiren gençlerin, sahip oldukları becerileri, kendilerinde aslında daha düşük seviyede olması gereken öz güven ve risk alma düzeyleri arasındaki harmoniyi yakalayamamaları gösterilebilir. Bazı araştırmacılar sürücü karar verme sürecindeki hiyerarşik yapıya atıfta bulunarak, stratejik karalarla taktiksel kararlar arasındaki farklılıkları açıklamışlardır. [4], Hollnagel et al., 2004)

Tüm yaş gruplarının toplamda en yüksek ölüm 2007 yılında 187 kişi olarak gerçekleşirken, en düşük değer ise 126 kişi ile 2013 yılında gerçekleşmiştir.

Yaş gruplarına ait ortalama ölümler incelendiğinde aşağıdaki grafik elde edilmiştir.

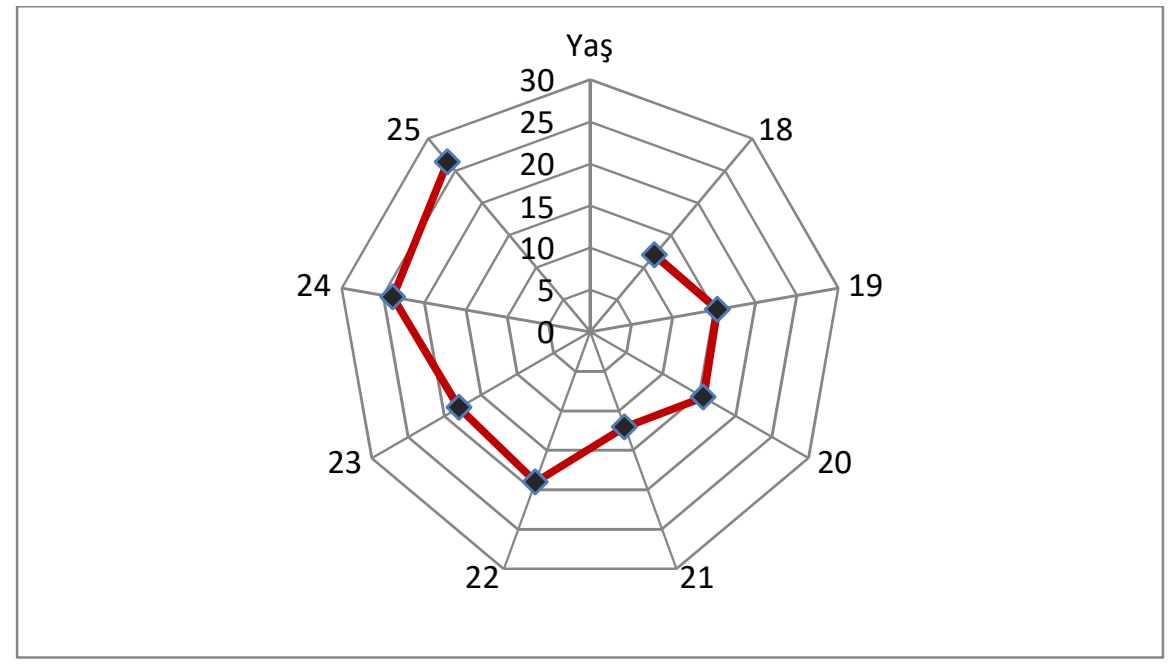

Şekil 3. 18-25 yaş grubu erkek sürücü yıllık ortalama ölümleri

Şekil 3 verileri incelendiğinde 18 yaş grubunun 11.94 ile en düşük, 25 yaş grubunun ise 26.39 ile en yüksek değere sahip olduğu görülmektedir. Aradaki yaklaşık \% 220 oranındaki fark, üzerinde dikkatle durulması gereken ve yukarıda belirtilen belirleyici faktörlerin dikkate alındığı uygun strateji ve uygulamaların aktive edilmesini zorunlu kılan bir tabloyu işaret etmektedir.

Erkekler için yaralanma olgusu incelendiğinde aşağıdaki şekillerde gösterilen durumlar elde 
edilmiştir.
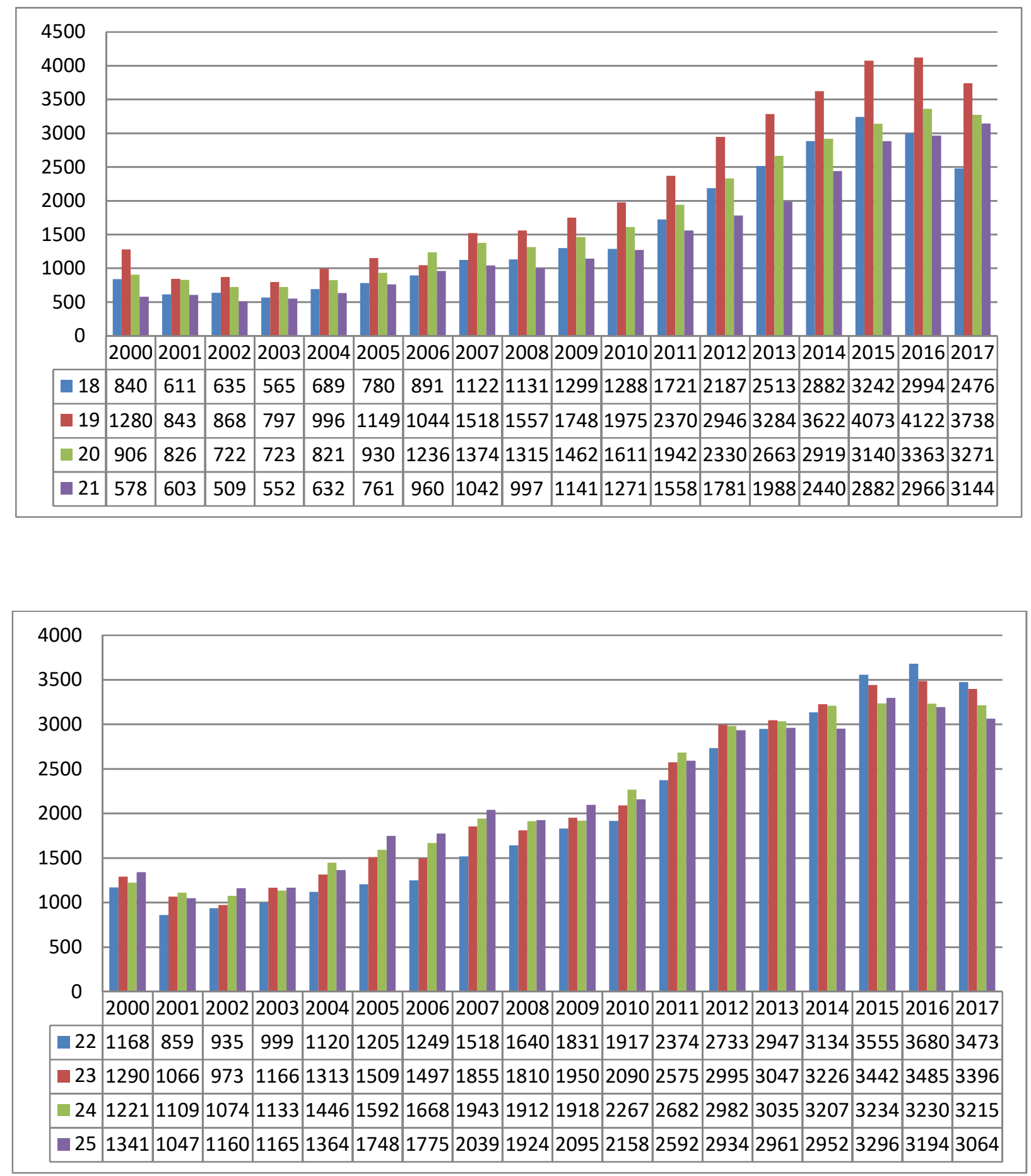

Şekil 4.a-b. 2000-2017 yılları arasında trafik kazalarında yaralanan 18-25 yaş aralığındaki erkeklerin sayıları

Mevcut bu genel veriler 1şı̆̆ında her bir yaş grubunun kendi içinde 2000-2017 yılları arasındaki yaralanma yüzdeleri aşağıdaki şekilde elde edilmiştir. 


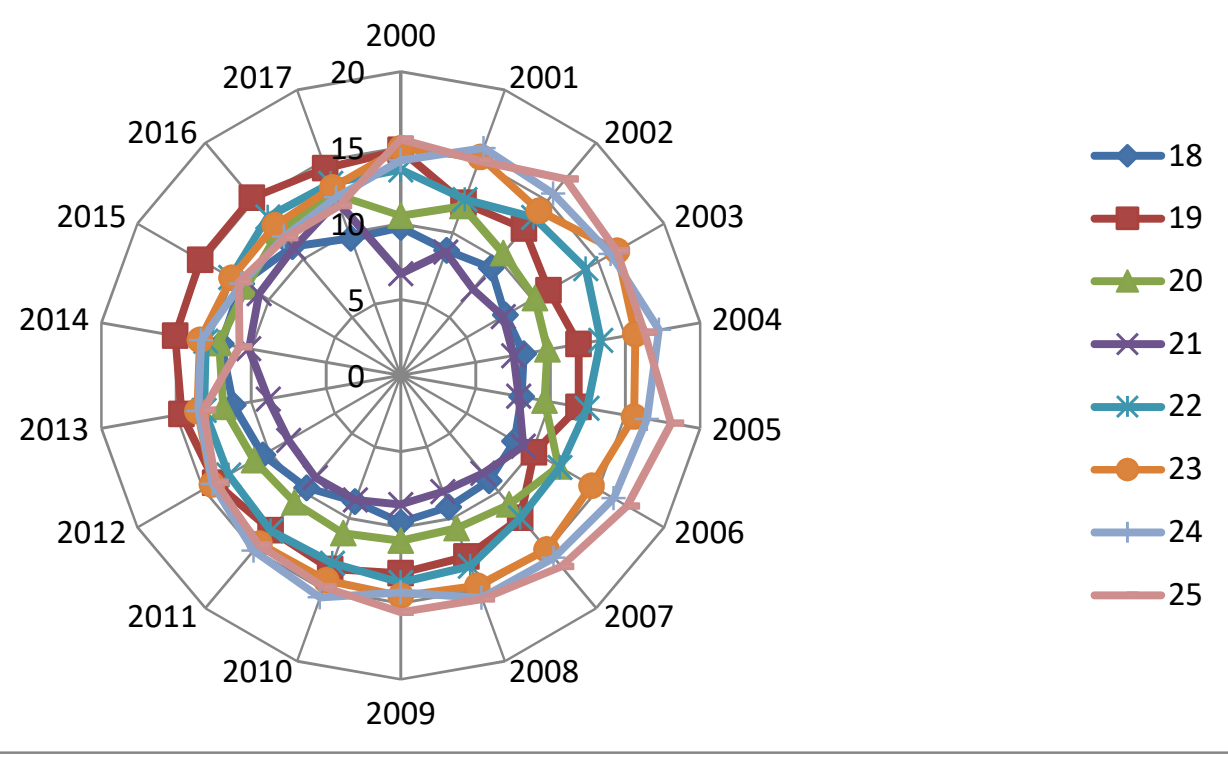

Şekil 5. 18-25 erkek yaş gruplarının 2000-2017 yıllarında kendi içlerinde yaralanma oranları

Ölüm oranlarında gözlemlenen yapıya benzer şekilde yaralanma oranlarında da 25 yaş öncül yaş grubu olarak öne çıkmaktadır. Yıılık bazda farklı yaş gruplarına göre en yüksek ölüm oranları 2000, 2001, 2002, 2003, 2005, 2006, 2007, 2008, 2009, 2010 ve 2011 yillarında 25 yaş grubunun sırasıyla en yüksek ölüm oranlarına $\% 15.55, \% 15.03, \% 16.87, \% 16.40, \% 18.07, \% 17,98$, $\% 16.43, \% 15.66, \% 15.58$ ve $\% 14.80$ sahip olduğu görülmektedir. 24 yaş grubu 2004 ve 2011 de $\% 17.25$ ve \%15.06; 23 yaş grubu 2012, 2013, 2014 ve 2015 yıllarında $\% 14.33, \% 13.58, \% 13.43$ ve \%12.86; 22 yaş grubu da 2016 ve 2017 yıllarında \%13.62 ve \%13.47 oranları ile diğer en yüksek yaralanma yüzdelerine sahip yaş gruplarıdır.

Tablo 3. 2000-2017 yılları arası 18-25 yaş aralığı erkek yaralanmaları Lineer Regresyon Analizleri

\begin{tabular}{cccccc}
\hline Yaş Grubu & $\begin{array}{c}\text { Regresyon } \\
\text { Denklemi }\end{array}$ & $\begin{array}{c}\text { Örneklem } \\
\text { Sayısı }\end{array}$ & $\mathbf{R}^{\mathbf{2}}$ Değeri & $\begin{array}{c}\text { Standart } \\
\text { Hata }\end{array}$ & $\begin{array}{c}\text { Standart } \\
\text { Sapma }\end{array}$ \\
\hline $\mathbf{1 8}$ & $158.94 \mathrm{x}+38.15$ & 18 & 0.85 & 366.94 & 920.17 \\
$\mathbf{1 9}$ & $211.63 \mathrm{x}+96.69$ & 18 & 0.88 & 429.35 & 1204.15 \\
$\mathbf{2 0}$ & $169.88 \mathrm{x}+139.92$ & 18 & 0.91 & 290.26 & 949.63 \\
$\mathbf{2 1}$ & $158.77 \mathrm{x}-74.71$ & 18 & 0.89 & 300.41 & 896.31 \\
$\mathbf{2 2}$ & $177.39 \mathrm{x}+327.91$ & 18 & 0.93 & 275.811 & 984.11 \\
$\mathbf{2 3}$ & $164.18 \mathrm{x}+589.49$ & 18 & 0.94 & 231.05 & 904.67 \\
$\mathbf{2 4}$ & $151.38 \mathrm{x}+721.24$ & 18 & 0.95 & 192.41 & 829.42 \\
$\mathbf{2 5}$ & $136.48 \mathrm{x}+839.49$ & 18 & 0.93 & 206.38 & 755.61 \\
\hline
\end{tabular}

Her bir yaş grubu için araştırma dönemi içinde maksimum ve minimum yaralanma oranları Tablo 4 de belirtilmiştir. 
Tablo 4. Yaş gruplarına göre erkek yaralanmalarında max-min oranlar

\begin{tabular}{ccc}
\hline Yaş Grubu & $\begin{array}{c}\text { Maksimum } \\
\text { Yaralanma } \\
\text { Oranı (\%) }\end{array}$ & $\begin{array}{c}\text { Minimum } \\
\text { Yaralanma } \\
\text { Oranı }(\%)\end{array}$ \\
\hline $\mathbf{1 8}$ & $11.634-2015$ & $2.028-2003$ \\
$\mathbf{1 9}$ & $10.867-2016$ & $2.101-2003$ \\
$\mathbf{2 0}$ & $10.658-2016$ & $2.288-2002$ \\
$\mathbf{2 1}$ & $12.184-2017$ & $1.972-2002$ \\
$\mathbf{2 2}$ & $10.155-2016$ & $2.371-2002$ \\
$\mathbf{2 3}$ & $9.008-2016$ & $2.515-2002$ \\
$\mathbf{2 4}$ & $8.320-2016$ & $2.763-2002$ \\
$\mathbf{2 5}$ & $8.572-2015$ & $2.723-2001$ \\
\hline
\end{tabular}

Tablo verilerine bakıldığında tüm yaş grupları için minimum yaralanma oranları açısından 2002 y1lı öne çıkarken, maksimum oranlarda ise 2016 yılı dikkat çeken değerlere sahip yıl olmaktadır.

Bayan sürücü ölümleri ve yaralanmaları açısından aynı yıllara ait veri analizleri yapılmış ve aşağıdaki sonuçlara ulaşılmıştır.

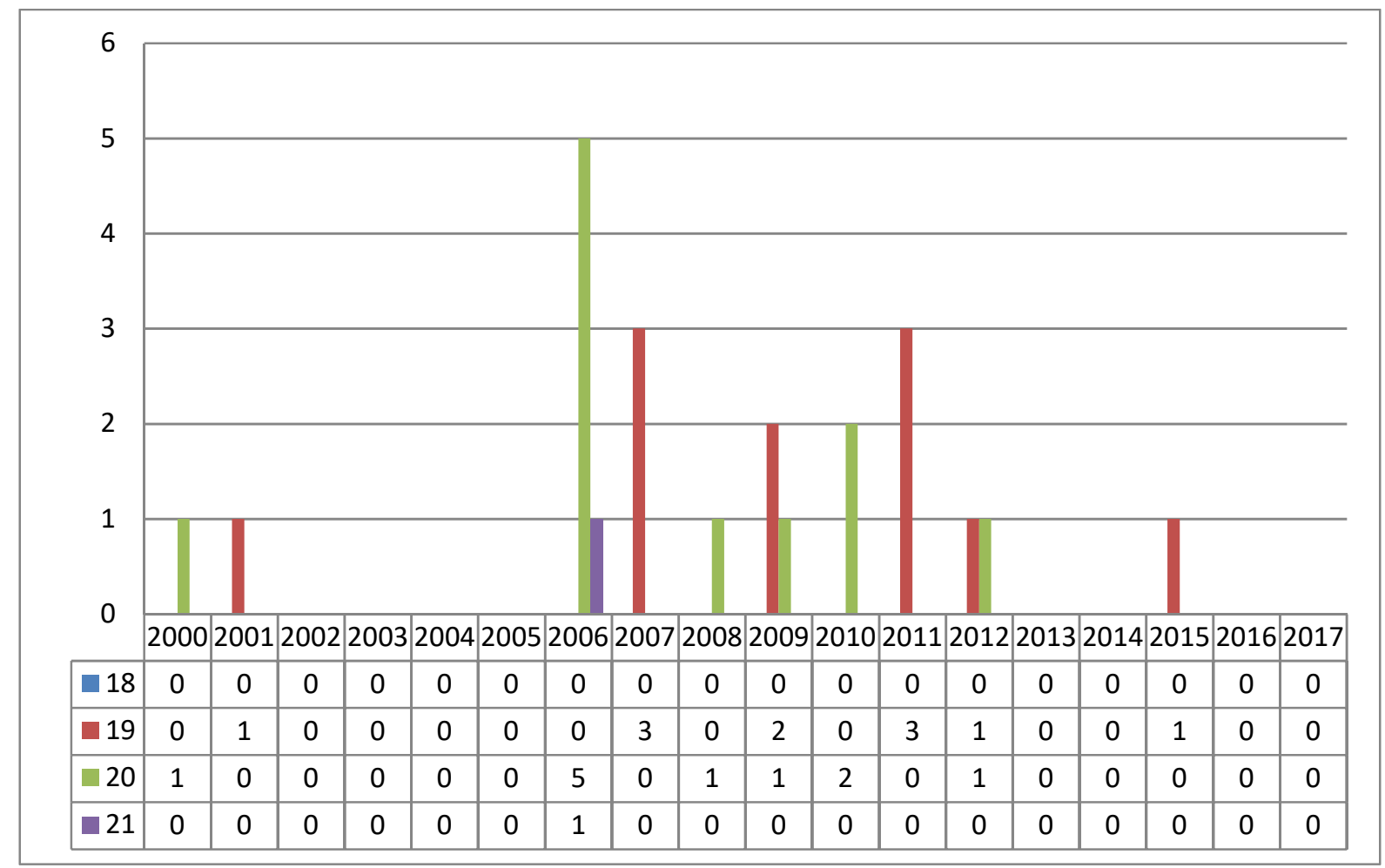




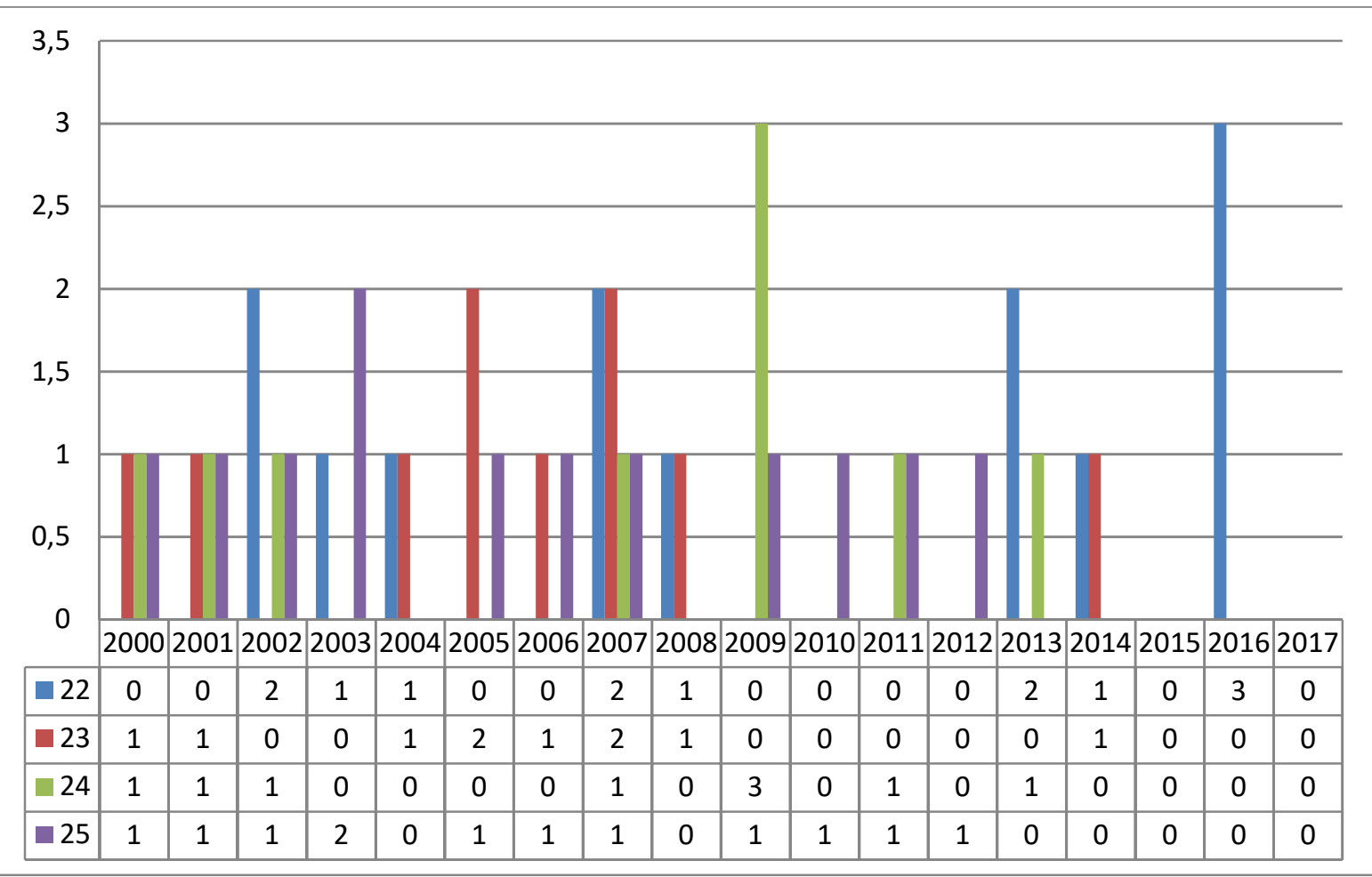

Şekil 6 a-b. 2000-2017 yılları arasında trafik kazalarında ölen 18-25 yaş aralığındaki bayan sürücü sayıları

18-25 yaş aralığında inceleme dönemine ait yıllarda sürücü olarak hayatını kaybeden bayan sürücü sayısının, aynı dönem ve yaş aralığındaki erkek sürücülere göre çok daha düşük olması, bu yaş grubundaki bayan sürücü sayısının ve pratik olarak yaptıkları toplam kilometraj değerinin, erkek sürücülere göre çok daha az olması ve risk alma eğilimlerinin göreceli düşük olmasının bir sonucu olarak değerlendirilebilir.

Yaralanan ( sürücü ve yolcu ) bayan sayısı açısndan veriler incelendiğinde aşağıda belirtilen ilişkiler elde edilmiştir. 

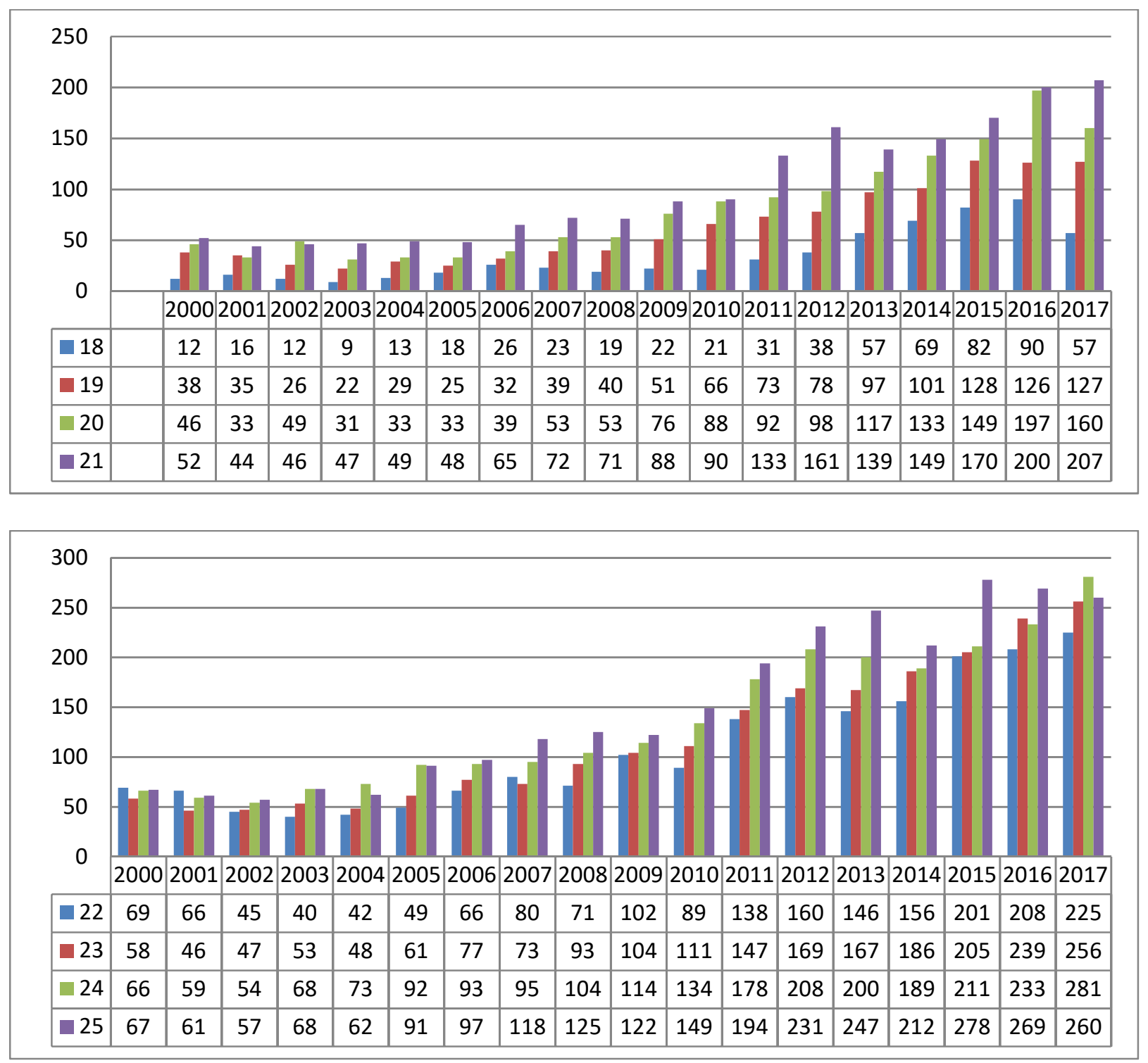

Şekil 7 a-b. 2000-2017 yılları arasında trafik kazalarında yaralanan18-25 yaş aralığındaki bayan sürücü sayıları

Tüm yaş grupları analiz edildiğinde erkekler için 2014, 2015, 2016 ve 2017 yıllarının en yüksek yaralanma değerlerini ihtiva ettiği görülmektedir. 18 yaş için en yüksek yaralanma sayısı 2016 y1lı için 2994 kişi, 19 yaş için 2016/4122; 20 yaş için 2016/3363; 21 yaş için 2016/2966; 22 yaş için 2016/3680; 23 yaş için 2016/3485; 24 yaş için 2015/3234 ve 25 yaş için ise 2015/3296 kişi olarak gerçekleştirmiştir. 2016 yılının bir çok yaş grubu için en yüksek yaralanmalı yıla tekabül etmesine ek olarak, 2010 yılını müteakiben tüm yıllarda yine yaralanma sayılarında artışlar gözlemlenmiştir. Bayanlar açısından yapılan analiz sonuçlarına göre 18 yaş grubunda 2016/90; 19 yaş grubunda 2015/128; 20 yaş grubunda 2016/197; 21 yaş grubunda 2017/207; 22 yaş grubunda 2017/225; 23 yaş grubunda 2017/256; 24 yaş grubunda 2017/281 ve 25 yaş grubunda 2015/278 verilerine ulaşılmıştır. Her ne kadar bayan yaralı sayıları erkek sayılarına göre düşük 
olsa da, her iki cinsiyette de 2015, 2016 ve 2017 yılları ortak yükseliş yıllarına tekabül etmektedir. Dolayısı ile yaralı sayısı açısından yükseliş eğiliminin olduğu bu dikkat çekici yıllara yol ve trafik güvenliği unsurları açısından daha detaylı bir inceleme süreci uygulanmalı ve elde edilecek sonuçlara göre uygun planlar ve stratejiler hayata geçirilmelidir.

Karşılaştırma olabilmesi adına çalışma yıllarında farklı yaş grupları ve cinsiyetlere göre ölüm ve yaralanma verileri aşağıdaki şekillerde sunulmuştur.

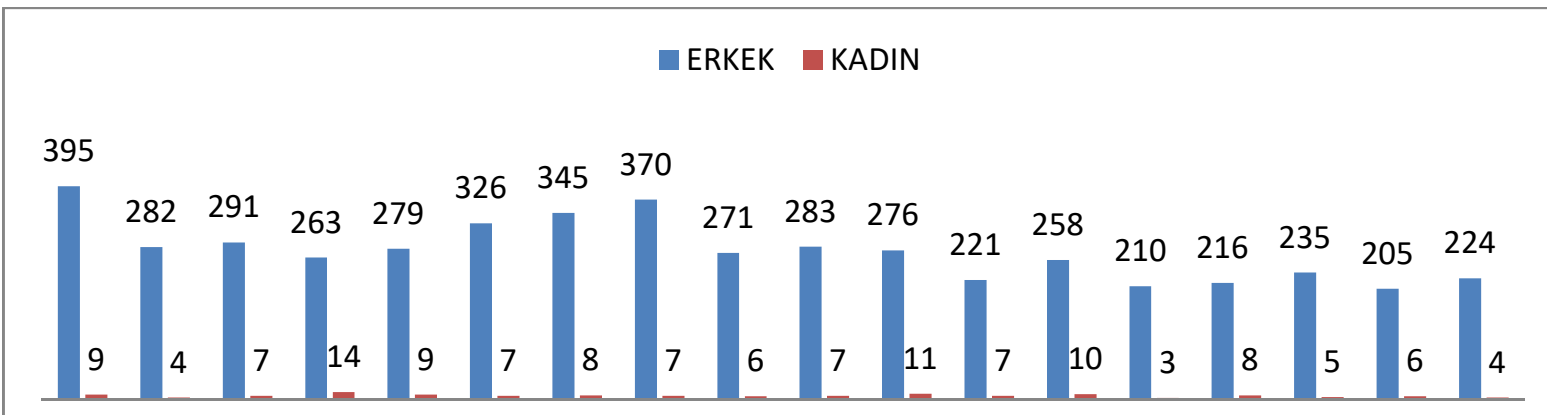

200020012002200320042005200620072008200920102011201220132014201520162017

Şekil 8. 25-34 yaş grubu Erkek -Kadın ölenlerin sayısı

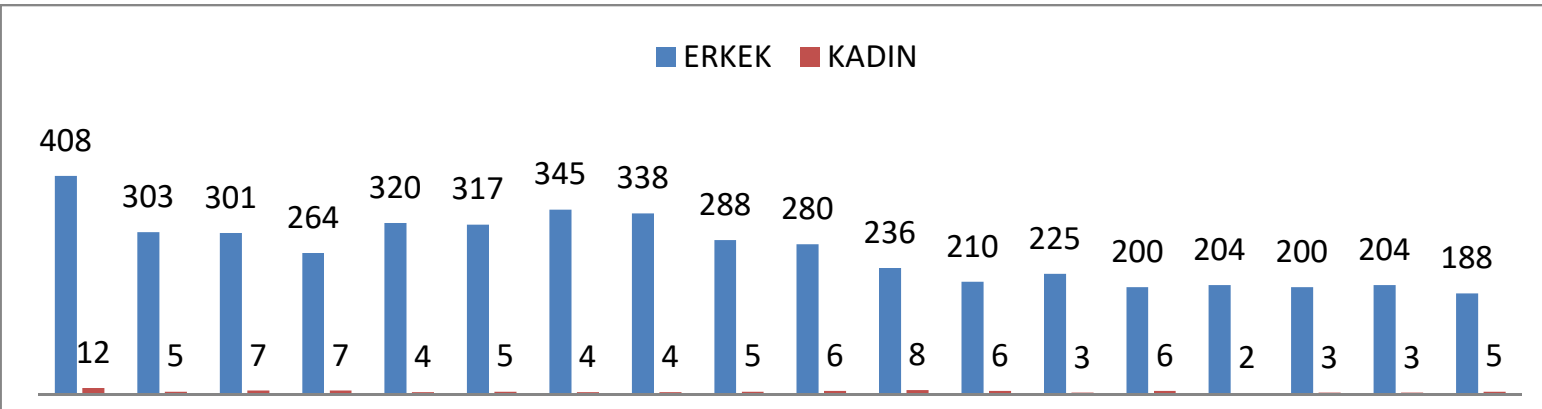

200020012002200320042005200620072008200920102011201220132014201520162017

Şekil 9. 35-44 yaş grubu Erkek -Kadın ölenlerin sayısı

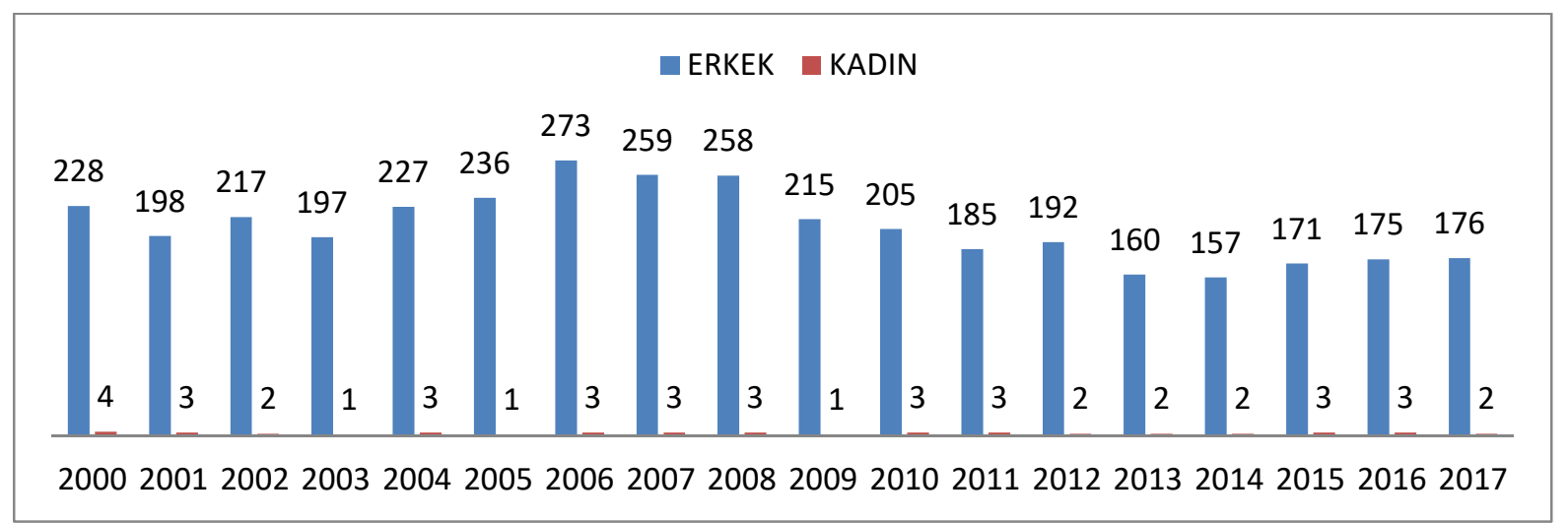

Şekil 10. 45-54 yaş grubu Erkek -Kadın ölenlerin sayısı 


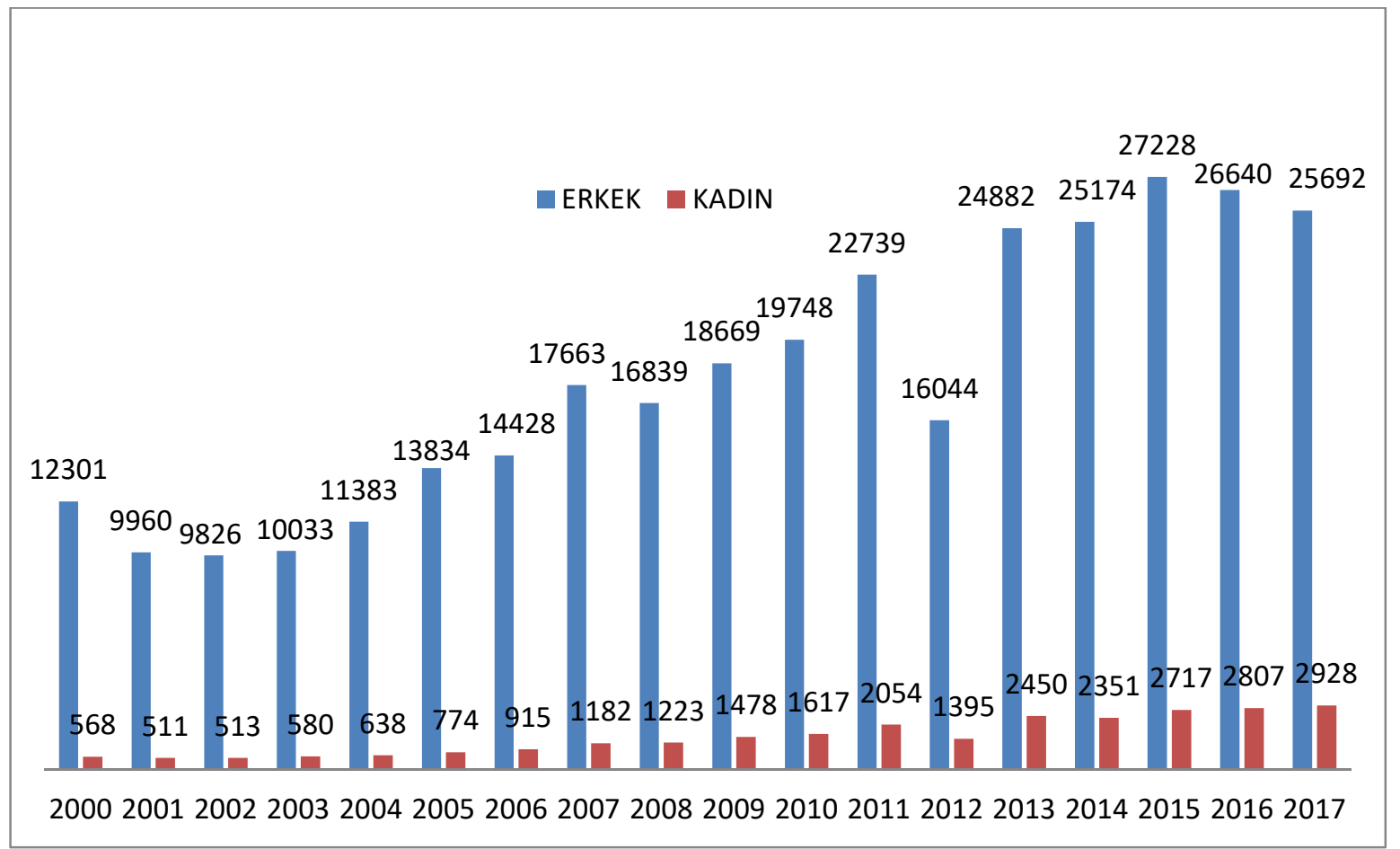

Şekil 11. 25-34 yaş grubu Erkek -Kadın yaralananların sayısı

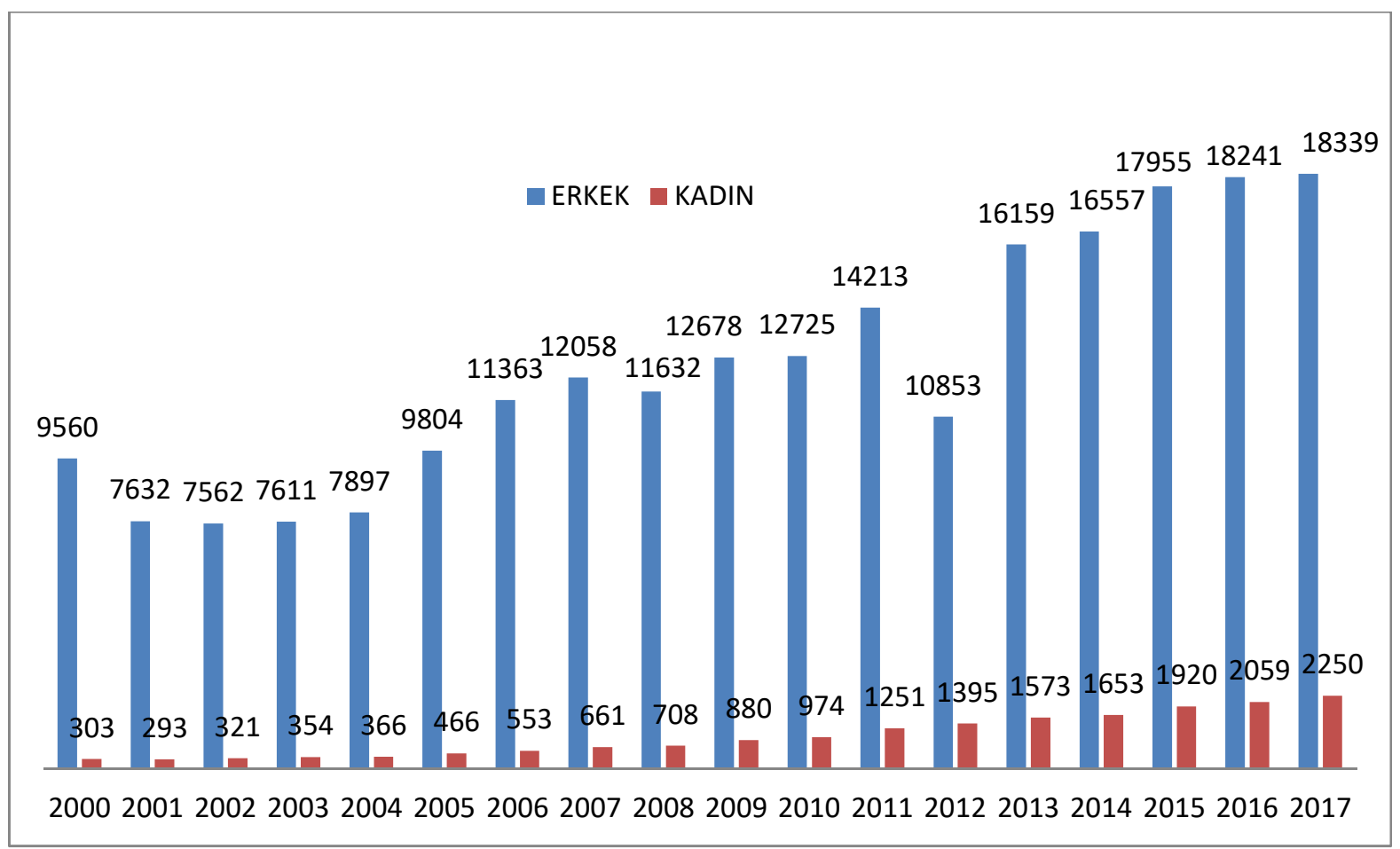

Şekil 12. 35-44 yaş grubu Erkek -Kadın yaralananların sayısı 


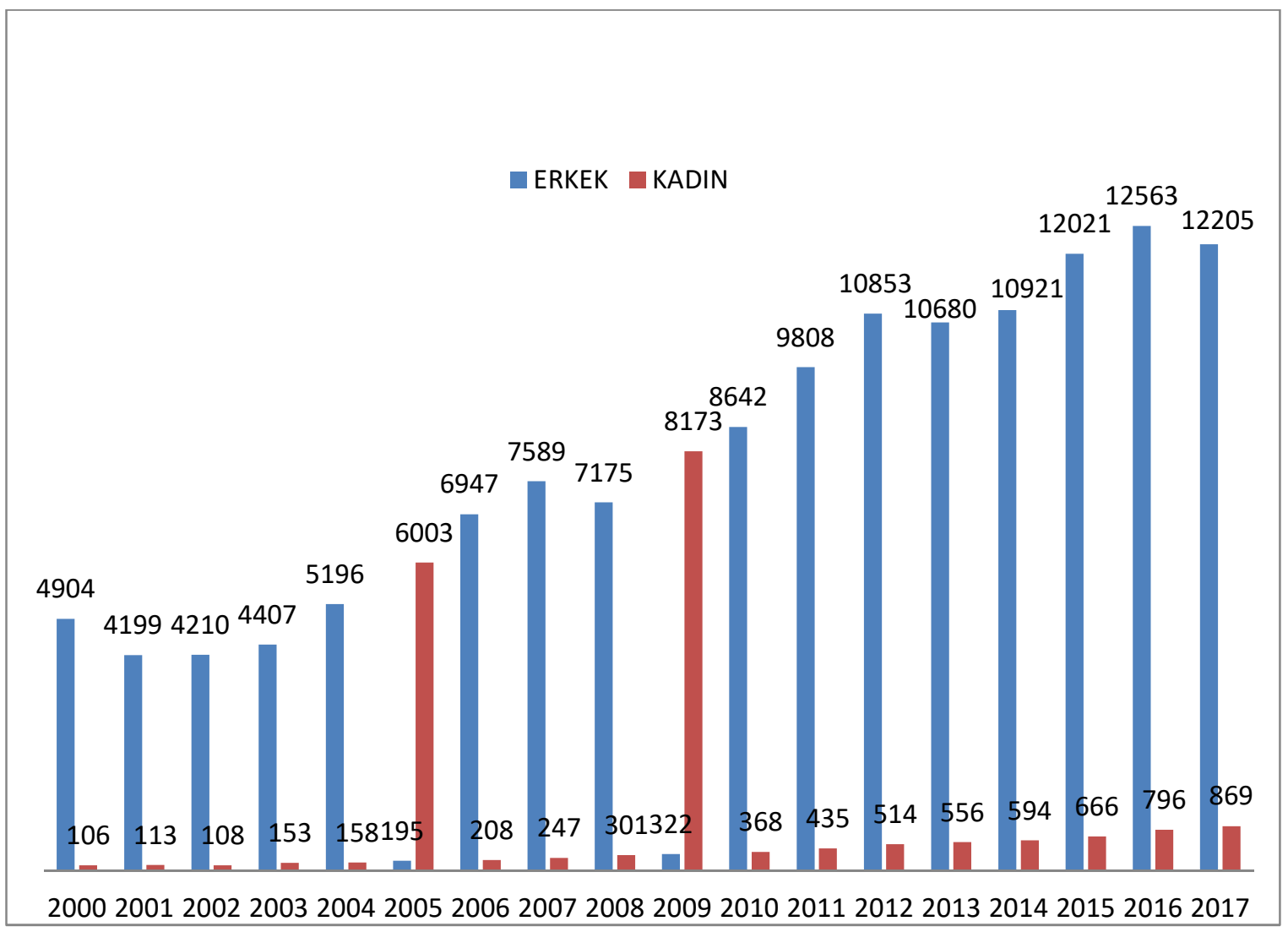

Şekil 13. 45-54 yaş grubu Erkek -Kadın yaralananların sayısı

\section{Sonuç ve Değerlendirme}

$\mathrm{Bu}$ çalışma içeriğinde 18-25 yaş grubunun trafik güvenliği konseptinde 2000-2017 yılları arasındaki ölümlü ve yaralanmalı kaza verileri gerek erkek, gerekse de bayan sürücüler ve yolcular açısından irdelenmiştir. Elde edilen bulgulara göre aynı yaş gruplarına ait bayan verileri ile karşılaştırıldıklarında, ölüm ve yaralanma sayılarında erkeklere ait değerlerin daha yüksek olduğu görülmektedir. Trafik ve hareketlilik taleplerinde daha aktif olan erkeklerde bu farkın ortaya çıkması belli oranda beklenen bir sonuç olmakla beraber, trafik kültürü ve özellikle genç erkeklerde mevcut trafik ortamını yeterince doğru algılayamama, gereksiz öz güven fazlalığı ve risk alma eğiliminin var olması da bu durumun ortaya çıkmasında etken faktörler olarak değerlendirilmelidir. Dünya Sağlık Örgütü ( WHO ), düşük ve orta sosyoekonomik düzeye sahip ülkelerde trafik kazalarına bağlı ölümlerle baş etmek için Hız, Alkol, Emniyet Kemeri, Çocuk Güvenlik Koltuklarl, Kask, Görünürlük gibi faktörlere odaklanılmasını önermektedir:. 18-25 yaş grubuna dönük olarak bu faktörlerin önemini ve yönetilmesini kavratacak uygulama süreçleri, 
eğitim pratiğine mutlaka dahil edilmelidir. Ulusal eğitim sistemleri sürücü adaylarını genellikle ehliyet sınavlarını geçmek üzere hazırlar ve sonra kendi hallerine bırakırlar. Bu eğitimlerde uygun güvenli davranışların tam olarak öğretildiği söylenemez. Deneyim esas itibari ile temel öğrenme süreci olarak kabul edilmeli iken, sınavı geçmeleri ile genç sürücüler 'deneyimli sürücü' kategorisinde değerlendirilmekte ve trafik atmosferinin her alanında yasal olarak yer alabilmektedirler.. Yapılan bir araştırmada eğitimin sadece \%5'inde kompleks ve tehlikeli manevralar, \%2'sinden azında ise tehlikeyi tanıma ve baş etme öğretilmektedir [5]. Denetim stratejileri iletişim kampanyalarıyla desteklenerek, algılanan yakalanma riski artırılmalıdır. Bu tür bir kampanyada amaç, risk almaktan kaçınma ihtiyacı ve bilinci oluşturmak olmalıdır. Yasal yapı, trafik sisteminin önemli bir elemanı ve düzenleyicisidir. Ölümlü ve yaralanmalı kazalara sebep olan temel parametrelere ait incelemeler ve analizler, hız, emniyet kemeri kullanımı ve alkollü araç kullanma, bu çalışma içeriğinde ilgili verilerden yapılmış olmakla beraber, bu makalenin hacmi açsıından bakıldığında dışarda bırakılmıştır. Bu parametrelerin etkileri bir sonraki makalede yayımlanacak olup, kaza sonuçlarıyla beraber, oluşum gerekçelerine zemin olacak etkin bir alt yapı oluşturulmuş olacaktır.

\section{Referanslar}

[1] Lisa Wundersitz, "Characteristics Identifying Young Drivers at a Higher Risk of Crashing” PhD Thesis, School of Psychology, University of Adelaide, 2007

[2] "Report: Young drivers and road safety in South Australia", Department of Transport, Energy and Infrastructrure, 2010

[3] "Young drivers: Crash Statistics For The Year Ended 31 December 2012" Ministry of Transport Report

[4] Hollnagel, E., Nabo, A., Lau, I.V., 2004. A systemic model for driver-incontrol. In: Proceedings of the Second International Driving Symposium on Human Factors in Driver Assessment, Training and Vehicle Design, pp. 86-91.

[5] Fuller, R., McHuch, C., Pender, S, 2008, Task difficulty and risk in the determination of driver behavior, Revue Européenne de Psychologie Appliquée 58(1):13-21

Emniyet Genel Müdürlüğ̈̈ Veri Tabanı 